\title{
Expanding the boundaries of beginning farmer training and program development: A review of contemporary initiatives to cultivate a new generation of American farmers
}

\author{
Kim L. Niewolny ${ }^{a}$ \\ Virginia Tech, Department of Agricultural and Extension Education \\ Patrick T. Lillard ${ }^{\mathrm{b}}$ \\ Texas A\&M University, Texas AgriLife Extension Service
}

Submitted 10 February 2010 / Accepted 29 March 2010/ Revised 14 May 2010 / Published online August 2010

Copyright (C) New Leaf Associates, Inc. 2010

\begin{abstract}
Beginning farmer training and program development in United States is one of the most significant yet poorly understood areas of agriculture, food system, and community development research and practice. This article offers a review of the social context informing recent beginning farmer educational programming in order to shed light on its development, purpose, and future trajectory. We provide several illustrations of best practices to support our main point that adult agricultural education for beginning farmers is taking on new forms and patterns to support and sustain a new generation of famers. As such it is vitalizing new opportunities to generate and exchange information and knowledge for sustainable agriculture. While these examples appear promising, the article concludes with recommendations for researchers and practitioners to expand the boundaries of what constitutes meaningful education for beginning

\footnotetext{
a 282 Litton Reaves, Virginia Tech, Blacksburg, VA 24061 USA; niewolny@vt.edu; +1 (540) 231-5784 (corresponding author) Station, TX 77843 USA; ptlillard@ag.tamu.edu;
}

b 225 HFSB, Texas AgriLife Extension Service, College +1 (979) 845-8567
\end{abstract}

farmers who are interested in sustainable food system models and practices.

\section{Keywords}

Adult agricultural education, beginning farmer, best practices, sustainable agriculture

\section{Introduction}

Beginning farmer training and program development is growing at a rapid rate throughout the United States. ${ }^{1}$ Development practitioners, educators, researchers, students, and farmers alike are currently experiencing the largest policy and

\footnotetext{
${ }^{1}$ Current beginning farmer definitions vary regionally, as they do nationally, and are the subject of current programmatic interest. We follow the USDA definition whereby "beginning farmers and ranchers are identified as those who have operated a farm or ranch for 10 years or less either as a sole operator or with others who have operated a farm or ranch for 10 years or less" (Ahearn \& Newton, 2009, p. 1). We use the term "beginning farmer" to include "beginning farmers and ranchers," unless otherwise noted. We recognize, however, that a number of terms referring to "beginning farmer" are used interchangeably by other organizations, such as "prospective farmer" (e.g., farmers who have not yet begun to farm) and "start-up farmer" (e.g., farmers who have been farming anywhere from one to ten years).
} 
program response aimed at creating new opportunities for people who have an interest in agriculture to begin farming. For instance, in fall 2009 the U.S. Department of Agriculture (USDA) awarded roughly $\$ 19$ million through the Beginning Farmer and Rancher Development Program (BFRDP). This first-time competitive grant program signifies an important point in time in the movement to support local and regional training, education, outreach, and technically based initiatives to address the critical needs of beginning farmers across the United States. Such a movement rests on a robust foundation built by many educators, scholars, and decision-makers whose advocacy aims are to develop viable community food systems that meet the needs of the next generation. The BFRDP, for example, was first authorized in the Farm Security and Rural Investment Act of 2002 (Farm Security and Rural Investment Act, 2002). The program remained dormant until mandatory funding for beginning farmer provisions was included in the Food, Conservation, and Energy Act of 2008 (Food, Conservation, and Energy Act, 2008). Of course, the history of beginning farmer educational programming can be traced to such earlier policy implementations as the 1992 Agricultural Credit Improvement Act, the Advisory Committee on Beginning Farmers and Ranchers in 1998, and the 2006 Small Farms and Beginning Farmers and Ranchers Regulation Policy, among others (Ahearn \& Newton, 2009; Ruhf, 2001). We might also think of the history of adult beginning farmer education in terms of the emergence of programs and services to enhance opportunities in sustainable agriculture, which is financially attributed to the USDA's Sustainable Agriculture Research and Education (SARE) program (Poincelot, et al., 2006) and private foundation support (Hesterman, 2006). It is further important to recognize the evolving participation of the land grant university and Cooperative Extension system in the history of beginning farmer research, education, and outreach through its many transformations since the 1862 and 1890 Morrill Land Grant acts, as well as the Smith-Lever Act of 1914 (Danbom, 1986; Rasmussen, 1960).
Beginning farmer training and program development is perhaps one of the most significant yet poorly understood areas of agriculture and food system research and practice. While agricultural training and education are prevalent worldwide, agricultural education research focusing on adult beginning farmers in the United States is limited. Most of the research reports are on educational and learning preferences of beginning or young farmers (see Nelson \& Trede, 2004; Trede \& Whitaker, 1998). While such issues are undoubtedly important, we are left with a limited view of the social, cultural, and political context that informs the educational experiences of adult beginning farmers in the United States. For example, little is known about the ways in which adult agriculture education acts as a conduit between beginning agriculturists and the wider social structures influencing food and farming systems, with the exception of analyses of gender and knowledge construction by Shortall (1996), Liepins and Schick (1998), and Trauger et al. (2008). Niewolny (2007) and others (Lamberti, 2007) have focused on the U.S. beginning farmer situation from cultural studies and discourse analysis perspectives to investigate how collaborative-based initiatives negotiate power relations that legitimate who can be a "new" farmer, what are agricultural practices for such farmers, and how agriculture can be written or talked about in public discourse by the practitioners who work with them. Disclosing such issues of power and knowledge enables us, according to Cervero and Wilson (2001), to better identify and respond to the ways in which our educational practice reifies or challenges inequitable conditions. From this perspective, food and farming systems research of adult beginning farmer education would benefit from more detailed exploration of the relevance of power in practice.

What does the practice of education look like? What purposes does it serve? And who is benefiting from it? Much adult education for beginning farmers is commonly understood to be located in colleges and universities, communitybased settings, Extension offices, agricultural workplaces, home and family activity, and other sites of nonformal education. When brought into 
the purview of the reflective practitioner (Schön, 1983), the notion of beginning farmer training and program development has been appropriated to designate everything from direct instructional activities in workshops, short courses, seminars, consultations, and traditional education classrooms to specialized experiential learning internships and apprenticeships, to informal mentoring and peer networking, and even to self-directed learning using Internet sites and social media. It becomes more difficult to understand this beginning farmer phenomenon when one tries to disentangle these types of educational formats from the many purposes that guide and inform the practice, such as issues in land tenure, financing, marketing, business planning, ecological stewardship, health, community engagement, and social justice. This is further complicated if we recognize how educational opportunities vary for social actors participating within and across different spatial boundaries: immigrants and refugees, urban and suburban agriculturists, women in farming, smallscale farmers, organic growers, transitional farmers, young farmers, mid-career changers, and new conventional commodity operators. While this flurry of beginning farmer activity is exciting for research and practice discussion, it is essential that we are critically conscious of the nature and purpose of this work. Now more than ever are we reminded that our agricultural education practice is not neutral territory where power relations can or should be ignored. We need to focus on the spectrum of issues informing our practice. In recent years, for example, our practice has variously responded to the excesses of the industrialized agriculture and food system through civic revitalization and social resistance (Hinrichs, 2007). According to Pretty (1995), our interpretations, assumptions, and world views about what constitutes our practice must be the subject of critical analysis and reflection if we want to transform the status quo toward more sustainable ends. It is the act of self-awareness and action that will lead us from a naïve to a critical consciousness, which enables us to better achieve more equitable and innovative outcomes in and from our educational practice (Freire, 1973).
This call for reflection is the catalyst for our inquiry into the beginning farmer phenomenon in the United States. That being said, the purpose of this review paper is twofold. First, we aim to provide the reader with an accessible yet critical assessment of the U.S. beginning farmer training and program development context by drawing upon a range of U.S. beginning farmer research (e.g., Niewolny, 2007), federal policy (e.g., Ahearn \& Newton, 2009), and programmatic literature (e.g., Sheils \& Descartes, 2004) that together provide a sociohistorical view of the beginning farmer situation in the United States. Here we emphasize the pedagogical underpinnings of the sustainable agriculture movement that illustrate the current trajectory of adult agricultural education for beginning farmers. Our second aim is to provide a descriptive summary of several beginning farmer initiatives that are instrumental in developing and exchanging knowledge for beginning farmers, particularly for farmers interested in sustainable agriculture. We start out by explaining the methods we used to identify and present the beginning farmer situation from these perspectives.

\section{Methods}

We drew upon a wide variety of literature to establish a review of the socio-historical context of beginning farmer training and program development and the initiatives that inform it. A problem in conducting a literature review such as this is that very few studies in agriculture and food systems use the terms "beginning farmer" and "adult agriculture education" as they are used in this study. Even fewer studies examine the emergence of beginning farmer education or the contemporary issues pertaining to its development. This lends a difficulty to defining the delimitations of a body of research. To manage this, we used a standardized review process to frame our inquiry. First, we searched the literature for such textual sources as scholarly research articles, popular press books, programmatic booklets, and organizational websites using the search terms "beginning farmer," "new farmer," "prospective farmer," "aspiring farmer," "adult agriculture education," "beginning farmer education," and "beginning farmer training." Here we focused on issues, 
policies, project development, and program outcomes of adult agriculture education for beginning farmers in the United States, with emphasis given to the post-Second World War era. We further narrowed our search by examining literature in rural studies, sustainable agriculture, and the sociology of agriculture to illustrate the intersection between contemporary beginning farmer education and the sustainable agriculture movement.

Second, we identified 33 beginning farmer initiatives that are illustrative of best practices currently used in beginning farmer training and programming. This data was collected from organizational websites, electronic and text-based program publications, and USDA competitive program resources. Initiatives were included in our review if they were offered between the years 1999-2009, to take into account the last ten years of training and programming. For instance, we did not include the 2009 awards from the USDA Beginning Farmer and Rancher Development Program, as these projects are to be developed over the next three years and are not yet in full practice. Additionally, we only included initiatives that could be defined as training, outreach, or educational programs or projects. If the initiative was identified as a project, the primary focus had to be training and/or education. We did not include production-oriented research projects that incorporated beginning farmers as subjects, as this would shift our focus away from the primary emphasis on programming and training. We also excluded one-time workshops, presentations, training sessions, meetings, and conferences. Instead we focused on initiatives that provided a continuum of educational programming. We recognize that this excludes several opportunities scattered around the country; however, our purpose here is to illustrate the most discernible and substantively driven initiatives that are instrumental in shaping the current programming and training trajectory. Similarly, we only included initiatives intended for beginning farmers in the United States. However, we included several initiatives that were designed for beginning farmers and the practitioners who work directly with the beginning farming community. Initiatives focused on general farming practices or for the public at large were excluded unless beginning farmers were clearly the main focus of the program or project. We further required that the initiatives were designed only for an adult farmer audience (i.e., above the age of 18), as compared to those programs and projects that are focused strictly on youth. For example, we did not incorporate the programs available to youth through the Future Farmers of America organization.

Lastly, we standardized our review process of the beginning farmer initiatives by focusing on similar aspects of the beginning farmer resource located on the organizational website or program document, such as mission, purpose, and justification statements. We further searched for primary educational formats, educational content, beginning farmer audience, geographical location, and the organizational collaborations and institutional contexts that the initiative operates within. We report on these findings below and in Appendix A.

While we believe this literature review is accurate and reliable, we acknowledge that information may have been omitted because our standardized review process did not take into account all beginning farmer educational research and program initiatives. Space considerations also made the case against a comprehensive review of all possibilities. Thus we have at a minimum provided the necessary starting point for more investigation and discussion. Our intention, therefore, is to present only an overview for the comparative purpose of clarifying recent developments so that we may improve our research and practice.

\section{"Mapping" the U.S. Beginning Farmer Phenomenon Issues and Outcomes}

Beginning farmer education for adult and young audiences in the United States is nothing new. While programs can be generally traced back to the advent of the Morrill Land Grant Act, scholarship analyzing the structure and practice of agriculture is most focused on the rapid changes of the past sixty years (Bird \& Ikerd, 1993). Following this view, we argue that it was not until the post-Second World 
War era that the beginning farmer phenomenon took hold, although in small and limited ways. Phipps (1956) and Heady (1957) demonstrate that although youth were largely targeted for beginning farmer education immediately after the war, education through public schools, vocational centers, and county Extension offices was made available to an array of older adult farmers, young farmers, and veterans of the First and Second World Wars. Heady (1957) and Rasmussen (1960) also argue that the training of young farm couples was encouraged through Cooperative Extension services at this time to prepare beginning farmers for necessary farm and home planning.

During the last several decades, practitioners, researchers, and policymakers across the nation have worked together in new and different ways to provide specific programs to maintain the viability of new farms, ${ }^{2}$ and the economic, social, and environmental fabric of which they are a part. For Niewolny (2007) and others (see Ruhf, 2001), these initiatives have formed as a growing social response to an overwhelming concern about the steady decline in the number of individuals entering into farming, coupled with an increase in the number of exiting farmers. In 2009, for instance, the U.S. Bureau of Labor Statistics reported a significant job decline for farmers and ranchers, and projected an 8 percent decrease in the number of farmers and ranchers between 2008 and 2018. There are several ways, however, that policymakers and food and farming advocates frame the issue. First, changes in the age distribution of farmers have sparked the interest of many decisionmakers. The rising age of U.S. farmers is perhaps the most apparent issue. According to the 2007 Census of Agriculture, the average age of a principal farmer was 57 years old, which is troubling when compared to the rapidly declining number of farmers in operation under

\footnotetext{
2 According to the 2007 Census of Agriculture (U.S. Department of Agriculture, National Agricultural Statistics Service, p. viii), a farm is "any place from which $\$ 1,000$ or more of agricultural products were produced and sold, or normally would have been sold, during the census year."
}

the age of 35. Put another way, Ahearn and Newton (2009) report that more than 63 percent of all established farms in 2007 had a principal farmer of 55 years of age or older, as compared to only 32 percent of beginning farm operations; they further caution that only 5 percent of all principal farmers were 35 years or younger in 2007. This aging population of U.S. farmers and ranchers is expected to increase by the next census while the number of young farmers is likely to decline.

Second, service providers and policymakers have started to recognize that not all paths to farm ownership and success are the same. Many agencies and organizations are now aware that beginning farmers have specific program needs that differ from experienced farmers. In 2006, for example, the USDA set forth the Small Farms and Beginning Farmers and Ranchers Policy to establish a systematic framework for addressing the special needs of small farms and beginning famers within the U.S. agricultural sector. While beginning farmers operate farms of all sizes, on average they operate smaller farms, in size and gross dollars, compared to established farms (Ahearn et al., 2005). In this view, it is not surprising that beginning farm development is often paired with small farm start-up strategies and approaches, such as special credit, financing, and outreach programs. Beginning farmers may also receive special assistance similar to farmers who are eligible for program support based on racial, gender, and immigrant status. For instance, the USDA provides programs for what it refers to as targeted-farmer groups $^{3}$, those comprising beginning farmers, limited-resource, and socially disadvantaged farmers, who together make up as much as 40 percent of all U.S. farms (Nickerson \& Hand, 2009). The nonprofit sector, individually and in

\footnotetext{
3 According to Nickerson and Hand (2009, p. iii) targeted farmers are those farmers "with 10 or fewer years of experience, farmers with limited farm sales and income, and farmers belonging to segments of the population that have historically been subject to discrimination, such as African American, American Indian, Alaskan Native, Hispanic, Asian American, or Pacific Island farmers."
} 
collaboration with other entities, has succeeded in providing several regionalized farm entry programs for women, immigrant, and other minority populations. Of note here are the Women's Agricultural Network (WAgN), the New Farmer Development Project (NFDP), and the New Entry Sustainable Farming Project (New Entry).

Third, a growing number of food and agricultural development practitioners and researchers contend that the social infrastructure currently supporting beginning farmers is not readily addressing their various needs (Ruhf, 2001). While the population and resource needs of beginning farmers differ from location to location, almost all experience similar barriers to successful farm startup. These barriers generally include high startup costs and limited access to available farmland for purchase or rent (Ahearn \& Newton, 2009). Beginning farmers frequently lack the capital necessary to be economically competitive using advanced technology and management practices, which is often the focus of leading research and education programs. These obstacles have been the focus of much debate in recent years. Literature ranging from Lockeretz and Anderson (1993) and Hassanein (1999) to Kloppenburg (1991), Gillespie (2004), and Lyson (2004) has variously set forth the argument that our current industrialized food and agricultural system radically influences the flow of knowledge, resources, and educational opportunities pertaining to agricultural production, distribution, and marketing so that they are also oriented along the same path; therefore, new kinds of farmers have been, and still are, faced with the challenge to acquire the much needed institutional and local support to exchange knowledge and build capacity for gaining access to suitable markets, capital, land tenure, hands-on training, and education that are necessary to develop and sustain food and farming activities. Poincelot et al. (2006) and others (Hassanein, 1999; Hassanein \& Kloppenburg, 1995) also argue that as traditional research and education institutions evolve, they struggle to address such changes and are not easily meeting the social, economic, and ecological needs of today's new farmers, particularly those interested in sustainable agriculture. A new educational infrastructure, however, is currently growing in size and scope as a considerable rejoinder to these critical issues. We now turn our attention to the ways in which this new kind of resource and information system is helping to cultivate a new generation of farmers.

\section{Toward an Alternative Knowledge System}

Contemporary beginning farmer initiatives have emerged from both the public and private sector. As previously mentioned, the USDA has granted beginning farmers special attention in the last several years. The majority of the policies and program expenditures sponsored by the USDA have taken the form of special credit and farm transfer programs designed to improve the competitiveness of new farms in the agricultural economy (Ahearn \& Newton, 2009). According to Ruhf (2001), the 1980 farm bill provided credit and debt forgiveness programs in the wake of the farm crisis. These funds, however, were meager and largely designated to maintain conventional agricultural operations. Broader support for beginning farmers developed in the 1990s. While the financial assistance programs remained in place, farmers were now able to apply for innovative conservation and farm succession programming (Ahearn \& Newton, 2009). With considerable help from the SARE program and other sustainable agriculture movement activity, this era also marks an important point in time when sustainable agriculture research, education, and outreach reached public visibility (Bird \& Ikerd, 1993; Poincelot et al., 2006). It is important to note that these new programs for beginning farmers looked different from their earlier counterparts. These new programs were established as organizational alliances to strengthen the educational infrastructure to better assist farmers and ranchers enter into agriculture, often including issues of sustainability that were emerging in public discourse. For instance, policy stemming from the 1990 farm bill provided the foundation for several new state, federal, and local partnerships to form in a number of ways as a means to facilitate new programs and services for the next generation of farmers (Niewolny, 2007). This thread of policy brought together such entities as public and private univer- 
sities and colleges, Cooperative Extension, state and federal agencies, and community-based organizations to provide programs and advocacy to formulate a different kind of agricultural service infrastructure to address the critical needs of beginning farmers. That is to say, these new collaborations and alliances signify an important shift in the design, purpose, and dissemination of adult agricultural education by incorporating a wide platform of social, economic, and ecological issues stemming from grassroot, land grant university, private research sector, and federal and state interests.

Three such initiatives are worthy of brief mention. First, the Center for Rural Affairs, a nongovernmental organization in Nebraska, was first and largely responsible for establishing a Land Link program with land grant university, governmental, and other grassroots support; this program largely focused on farm transfers between retiring and entering farmers (Ruhf, 2001). According to Lamberti (2007), the Beginning Farmer Center (BFC) illustrates another attempt to foster successful farm startups through the partnership of several entities. The BFC was created in 1994 through the collaborative efforts of the Iowa State University Extension and Iowa State Department of Agriculture. Similarly to the Center for Rural Affairs in Nebraska, the BFC developed in response to concerns about the low number of farmers entering and surviving in the Midwest agricultural sector. Today the BFC continues to focus on farm transition services while providing several online resources and communication materials to match prospective farmers with existing farmers to pass along operating farm businesses to the next generation. Finally, the Growing New Farmers (GNF) Project, a four-year initiative, was the first large-scale model of beginning farmer education that responded to challenges facing new and prospective farmers in the northeastern region of the United States (Niewolny, 2007). Financially and programmatically administered by the New England Small Farm Institute, in 2001 the GNF Project initiated the Growing New Farmers Consortium (GNFC) to develop comprehensive programs, research projects, professional development services, and policy advocacy to assist farmers with the difficulties of establishing new farm operations in the Northeast, such as gaining access to markets, capital and credit, education and training, and obtaining farmland (Sheils \& Descartes, 2004). By the end of the project, over 200 organizations throughout the twelve-state region participated as members, thus providing an array of programs and projects intended for beginning farmers, beginning farmer educators, and service providers.

Other networks and alliances continue to grow in number across the United States. While these initiatives provide different services and programs, a common goal guiding their actions is to provide suitable information, training, and learning opportunities to assist people in establishing and retaining new farms because traditional forms of education are not addressing their needs. This emerging interest in building an alternative foundation for farmer knowledge and resource exchange, however, has not occurred in isolation. For the last several decades researchers and practitioners have contemplated the emergence of a growing social movement that is creating opportunities for the exchange of new and experiential knowledge among farmers and others about sustainable agriculture (Hassanein, 1999). While many definitions of sustainable agriculture exist, we refer to Lyson's (2004) civic agriculture framework to identify a model of agriculture that is premised on the production, distribution, and consumption of local and regional food that is economically, ecologically, and socially viable.

Following Allen (2004) and others (Allen \& Sachs, 1993), we further argue that the boundaries of the sustainable agriculture movement are diffuse across time and space; however, there is an advocacy contingent that radically opposes the industrialization, corporate governance, and adverse social and ecological consequences of agribusiness practice and policy. According to Lyson (2004), this movement has mobilized efforts to transform the prevailing industrialized model of U.S. agriculture into a more civically organized system that "brings together production and consumption 
activities within communities and offers consumers real alternatives to the commodities produced, processed, and marketed by large agribusiness firms" (p. 101). For Butler and Flora (2006) and Lockeretz \& Anderson (1993), this movement has not only provided the groundwork for social advocacy and resistance to the dominant model, but also has helped to create alternative forms of knowledge, networks, and standards of agricultural practice that traditionally operate outside formal institutions of research and education that historically favor the industrialization model. Such alternative knowledge often disputes conventional science and educational agendas through what Kloppenburg (1991) describes as a form of "environmental and agrarian activism" (p. 519). From this perspective, the process by which new agricultural knowledge is created is grounded in participatory democracy as both the means and ends for pragmatic learning for food system transformation (Hassanein, 2003). For Chambers (1997), Hassanein (1999), and Röling and Wagemakers (1998), this means educators and decisionmakers need to emphasize the value of local knowledge, stakeholder participation, community dialogue, experiential learning, and social networking at local and institutional levels. In doing so, we not only develop new knowledge about ecological agriculture or organic farming, but also reveal critical concerns of our agricultural communities. The ways in which this can occur varies from implementing participatory learning methods in short courses and workshops to offering certification, farm incubator, and apprenticeship programs in sustainable agriculture. While still considered alternative, these pedagogical approaches are increasingly taking root in agricultural education circles at local, regional, and national levels under the umbrella of sustainable agriculture (Allen, 2004).

Röling and de Jong (1998) make the case that these pedagogical views differ from the prevalent transfer-of-knowledge model commonly associated with traditional extension education; therefore, they are difficult to incorporate into mainstream agriculture through public institutions of research and education. For Niewolny (2007) and Niewolny and Wilson (2007), collaborative beginning farmer programs seeking to change the way agricultural knowledge is presented and disseminated to new agriculturalists also struggle to break free of conventional views and practices of agriculture given that they are historically entrenched in neoliberal and technical rational discourse, which together fuel the agricultural industrialization process. Yet Niewolny's (2007) research on the Growing New Farmers Consortium recognizes several promising efforts that illustrate a possible shift in design and purpose of adult agricultural educational toward sustainable ends. Poincelot et al. (2006) also demonstrate how the sustainable agriculture agenda is becoming more apparent in traditional extension education programs and services through such topics as integrated pest management, reduced or no tillage, agroecology, and other environmental forms of production. In the following section, we briefly highlight promising illustrations that support the point that beginning farmer training and programming are perhaps taking hold in new ways, and thus vitalizing new opportunities to create and exchange information and knowledge about and for sustainable agriculture.

\section{New Initiatives for Beginning Farmers}

Appendix A is a descriptive summary of the 33 beginning farmer initiatives reviewed. We organized the summary by mission and purpose, audience, geographical location, educational content, educational practice or approach, and the social context in which the initiative operates. We report on the several themes that help define best practices for beginning famer programming, especially for those interested in sustainable agriculture.

\section{Establisbing New and Sustainable Farms}

The results of reviewing 33 initiatives show that they vary greatly in their educational purpose, which range from revitalizing food and farming activity in specific regions where farmers require startup assistance, to developing agriculture leadership for the next generation, to assisting new farmers to become successful biodynamic and organic farmers, to increasing the number of 
women and immigrant families owning and operating profitable and small-scale farms. Generally, an impressive share of initiatives appear to focus on increasing the number of viable farmers and farms, with little to no specification about the kind of agriculture in which these farmers would or should be involved. More specifically, however, we suggest that most initiatives aspire to increase awareness of and involvement in sustainable agriculture through explicit reference to sustainable agriculture in their mission statements. The Seed Farm, People

Learning Agriculture Now for Tomorrow (PLANT), New Farmer Foundation Year, and Cultivating Success are a few examples among others that publicly convey their programming using overt "sustainability" language. A number of initiatives also aim to provide farmers with an opportunity to learn about specific sustainable agricultural practices, including organic, pasturebased, and biodynamic farming. For example, the University of California-Santa Cruz (UC-Santa Cruz) Apprenticeship in Ecological Horticulture and the Michigan State University Organic Farmer Training Program provide hands-on training in organic agriculture as a form of sustainable agriculture.

Not all of the initiatives frame their program's mission using this kind of language. For example, the Farm Bureau's Young Farmers and Ranchers program takes on a different view in that the program is generally designed to develop agricultural leaders for the agricultural industry. The Young Farmers and Ranchers program material we reviewed, however, referred to the national program and how it operates at the state level. Each program likely differs from state to state or region to region. In this view, we cannot determine from the findings if sustainable agricultural issues and practices are present in their particular programs for young farmers.

\section{Many "Beginning Farmer" Audiences}

Defining the "beginning farmer" is perhaps one of the most critical issues for practitioners and decision-makers. Several factors influence how programs define their beginning farmer audience.
These factors include participants' level of farming awareness, experience, and commitment. It also includes consideration for the ways in which farmers experience agriculture through different cultural lenses. We found that beginning farmer initiatives across the country provide targeted programs for such groups as immigrants and refugees with farming experience, new urban agriculturists, women in farming, mid-career changers, individuals interested in small-scale farming, exiting and entering farmers, farmers between the age of 18 and 35, and even farmers who are starting to explore the idea of farm startup. Several programs are also designed for a general, beginning farmer audience. This audience usually comprises a range of prospective, new, and semiexperienced famers in a range of content areas.

These examples reflect the diversity of audiences we have indentified in our findings. From this diversity, we found that "new" and "beginning" farmer language is most common as compared to targeted audiences. This suggests that a majority of these initiatives are designed to assist a wide range of individuals who are aspiring, planning, and starting to farm.

We also found that a number of the programs designed for targeted audiences (e.g., immigrant farmers, women agriculturalists, and entering and exiting farmers) not only operate at the local level but also participate in regional and national networks of projects and programs that support their particular programming needs. While this is an interesting finding, we do not fully report on the purpose and format of each network, given space limitations. Instead, we suggest that readers contact program administrators to learn more about these networking opportunities.

\section{Beginning Farmers Require More than Just Technical Skills}

The content of these programs and projects cover numerous topics and issues, most of which are focused on five core areas: production practices, marketing, financial planning and resource assistance, business planning and management, and land acquisition and transfer. Within each core area 
we located topics that ranged from organic production practices to small-scale farm management to developing community supported agriculture (CSA) opportunities. Although there is considerable variety, we found that in general these content areas emphasize substantive issues, concerns, and practices that move beyond standard technical assistance programming. For example, exploratory programming is fairly prevalent. These kinds of programs are designed to help potential or prospective farmers assess their goals, values, and expectations to see if farming is really what they want to do. They cover a range of topics, including marketing, small business planning, lifestyle assessment, and whole farm planning. This is best demonstrated by the New England Small Farm Institute's (NESFI) Exploring the Small Farm Dream course. NESFI not only provides the coursework and a booklet, but also offers train-the trainer programming for educators across the country.

While the topic of social networking is most closely associated with the means by which farmers learn, it is another area of content that stands out in the findings. Several initiatives explicitly provide social learning opportunities for participants to build social networks for farming success. The Agriculture and Land-Based Training Association, for example, provides farmer training and group dialogue learning opportunities for farm workers, limited-resource farmers, and aspiring farmers. This program appears to provide networking opportunities for participants to learn together for purposes that range from civic education to community leadership. The Beginning Farmer and Land Access Program is another initiative that integrates network-building into its programming to help newly established farmers obtain material and community resources, including land, capital, and social support.

\section{Forget the Lectures: Learning on the Farm (and Online)}

We identified several educational formats and practices that go beyond the traditional transfer-ofknowledge approach. These approaches generally focus on the local knowledge of the farmer- participant through such hands-on and experiential learning methods as farmer-led training and mentoring, on-farm training through apprentice programs, and goal-evaluation courses and workshops. These approaches, however, vary in depth and scope given that content delivery models differ among the initiatives. The formats range from in-class courses, in-depth training and technical assistance programming on farms, to an integration of classroom and on-farm learning, and even to self-directed webinar and online courses.

Several issues stand out from these findings. First, we found that the Internet appears to have opened new possibilities for delivery methods of educational programming intended for beginning farmers. Many online courses and resources are viable options for individuals interested in learning about the nuances of agriculture and farming practices. These online educational opportunities provide many benefits as they can be accessed anywhere and at the convenience of the learner. They also provide viable options for networking with individuals from other geographical locations who would otherwise be difficult to reach. This is best illustrated by two different initiatives: Beginning Farmers from Cornell University and Cooperative Extension, and The Greenhorns's Guide for Beginning Farmers, a special project of The Greenhorns. While they provide different programming, each utilizes forms of social media (e.g., YouTube and blogs) as a means to create new spaces of learning for beginning farmers.

Second, we identified two types of programs that are designed to engage the learner on the farm using an experiential-learning, apprentice design. These include certificate programs and farmerorganized apprentice networks. Of these, the UCSanta Cruz Center for Agroecology and Sustainable Food Systems is perhaps most recognized for its six-month experiential learning apprentice program, which has been offered since 1967. Michigan State University's Organic Farmer Training Program is also designed to provide learners with an intensive, hands-on experience. Collaborative Regional Alliance for Farmer Training (C.R.A.F.T.) is an example of a farmer-based apprentice 
networking program that differs from the first two in that it emphasizes community-based learning whereby experienced farmers cooperatively organize on-farming learning opportunities to enhance the educational experience for farm apprentices.

\section{Regionalization and Place-based Programming}

Many of the initiatives we reviewed serve a particular region or community through placebased programming. This place-based approach typically underscores the importance of the local farming context, the programming needs of local area beginning farmers, and the personal knowledge they bring to the farming experience. From our findings, there appears to be a particular emphasis on East and West Coast training and programming and the issues that pertain to those farming regions. There are a handful of initiatives, however, in the Midwest, most of which identify with a particular farming community. For example, the Practical Farmers of Iowa (PFI) aims not only to address the distinctive needs of beginning farmers in Iowa, but particularly the beginning farmer members of PFI through its Next Generation program.

When we looked closely at the regionalization of the initiatives, we noticed that a few operate as national networks of projects and programs. These kinds of initiatives tend to function in one of two ways. First, a few initiatives represent national organizations that have statewide programs. The American Farm Bureau, for instance, is a nongovernmental organization whose scope is national yet provides individual, state-level services through its Young Farmers and Ranchers program. Second, several place-based programs are tied together through a larger networking initiative that has far greatear visibility. The National Farm Transition Network best illustrates this idea. This network comprises 20 Farm/Land Link projects that work both together and individually to provide land acquisition and transfer programming. Each program varies in organizational structure, however, and therefore functions uniquely to serve its specific beginning farmer audiences. For instance, Pennsylvania Farm Link does not share a similar history or facility with other programs, such as the much younger Farm Link program in Virginia.

Collaborative Structure and Organizational Alliances The results also indicate that these programs and projects vary in organizational structure. They range from simple one-organization projects to highly collaborative partnerships among nongovernment organizations, farmer networks, land grant universities, Extension associations, and government institutions. These collaborative initiatives are common and appear to be growing in number, with several organizational partners building alliances in order to develop or provide ongoing programming, some with national scope, for beginning farmers. Some are formal while others operate very loosely and informally. The Vermont New Farmer Network, for example, is an informal alliance of regional organizations and institutions whose goal is to coordinate communication and programming to serve the needs of new and aspiring farmers in Vermont. The Growing New Farmers (GNF) Project Consortium is perhaps the foremost example of multi-institutional and multi-organizational collaborative programming, with roughly 200 beginning farmer entities offering a wide range of training, mentoring, and technical assistance programming. Like the GNF Project, most of the collaborative initiatives developed over time as compared to those whose partners came together initially to launch a program. For example, The New Farmer Development Project (NFDP) was established in 2000 as a partnership between Greenmarket and the New York City Cornell Cooperative Extension Program. Over the last nine years the project has grown to serve new immigrant populations in communities surrounding New York City through the program support of such organizations as Just Food, NY Farm Link, and the Northeast Network of Immigrant Farmer Projects.

\section{Conclusion and Recommendations}

By drawing upon applied research, federal policy, and programmatic literature, we have illustrated how beginning farmer training and program development is moving in a "sustainable" direc- 
tion. In particular, we argue that the beginning farmer phenomenon is helping to build the foundation for an "alternative knowledge system" that functions at local, regional, and national levels for the development of sustainable agriculture and food systems (Hassanein, 1999, p. 6). This is illustrated by the way in which policy and funding opportunities for beginning and small-scale farmers parallel an increasing trend in sustainable agriculture research, education, and outreach. This is also illustrated through specific program and project opportunities that emphasize sustainable agriculture teaching and learning practices, including experiential learning, peer learning, mentoring, nonformal certification programming, social networking, incubator projects, and various forms of online learning. These training and programming opportunities also comprise a laundry list of content areas that move beyond conventional agricultural views and practices, including but not limited to land conservation and land acquisition, niche and direct marketing, organic farming, whole farm planning, farmworker rights, and personal goal assessment.

Drawing upon Niewolny (2007) and others (Niewolny \& Wilson, 2007), we are also reminded that this newly formed knowledge base for new kinds of farmers is only now gaining traction to address special startup and community development needs. Sustainable agriculture education and beginning farmer education are yet positioned at the margins of major research and education agendas. From this perspective, it is important to assess our practical and political achievements to better identify how we can improve the situation on the ground. This paper is an attempt to begin that crucial conversation. There is much more to be accomplished. In building upon these ideas, we can continue to expand the boundaries of what constitutes meaningful programming for beginning farmers. The following points are only a few recommendations for research and practice from this perspective.

\section{Recommendations for practitioners}

- Incorporate community-based learning strategies to build viable social networks for facilitating successful beginning farmer learning communities. These strategies might include community forums, study circles, focus groups, and collaborative leadership development.

- Implement participatory and experiential learning methods that integrate beginning farmer knowledge with trainer experience. Reduce the amount of lectures and other forms of direct instruction.

- Integrate social media forums to generate and sustain interest in agriculture for the digitally aware beginning farmer audience.

- Integrate new approaches to establish, retain, and expand sustainable agriculture concepts and activities into everyday practice. For example, introduce local and regional food system marketing coursework and social networking, farm-to-fork programming, and scaling-up business incubator programs.

\section{Recommendations for researchers}

- Explore the social and cultural impacts and implications of beginning farmer programs through ethnographic and critical analysis of on-the-ground, everyday practice and curriculum materials.

- Investigate how beginning farmer organizational alliances negotiate power and interests among organizational entities through the program planning process.

- Conduct in-depth study of best practices for incorporating civic agriculture concepts into higher education beginning farmer curriculum.

- Investigate the role community food system development entities (e.g., food system councils) play in facilitating opportunities for beginning farmers to establish and sustain operations using a community-based participatory research (CBPR) framework. 
Journal of Agriculture, Food Systems, and Community Development ISSN: 2152-0798 print / 2152-0801 online

www.AgDevJournal.com

\section{Acknowledgements}

We would like to thank our colleagues at Virginia

Tech, Texas A\&M University, and Cornell

University for supporting earlier versions of this

research. We also appreciate the encouragement of our friends and colleagues in the Sustainable

Agriculture Education Association (SAEA).

\section{Appendix A}

Summary of Beginning Farmer Initiatives 
$\bowtie$ Appendix A: Summary of Beginning Farmer Initiatives

\begin{tabular}{|c|c|c|c|c|c|c|}
\hline Initiative & Mission/Purpose & Audience & Content Area & Educational Format & Social Context & Location(s) \\
\hline $\begin{array}{l}\text { Agriculture and } \\
\text { Land-Based } \\
\text { Training } \\
\text { Association } \\
\text { (ALBA) }\end{array}$ & $\begin{array}{l}\text { "[A]dvance economic viability, social } \\
\text { equity and ecological land } \\
\text { management among limited-resource } \\
\text { and aspiring farmers." }\end{array}$ & $\begin{array}{l}\text { Farm workers } \\
\text { and limited- } \\
\text { resource, } \\
\text { aspiring } \\
\text { farmers }\end{array}$ & $\begin{array}{l}\text { "Basic civics and } \\
\text { policy education," } \\
\text { business planning and } \\
\text { management, funding, } \\
\text { leadership, marketing, } \\
\text { production }\end{array}$ & $\begin{array}{l}\text { Courses, farmer- } \\
\text { lead networking, on- } \\
\text { farm training }\end{array}$ & $\begin{array}{l}\text { Partners from } \\
\text { government agencies, } \\
\text { nongovernmental } \\
\text { organizations, and } \\
\text { university and extension } \\
\text { associations }\end{array}$ & $\mathrm{CA}$ \\
\hline $\begin{array}{l}\text { Apprenticeship in } \\
\text { Ecological } \\
\text { Horticulture }\end{array}$ & $\begin{array}{l}\text { "[l]ncrease the number and diversity } \\
\text { of individuals who have a command } \\
\text { of the fundamental skills and } \\
\text { concepts associated with organic } \\
\text { horticulture and agriculture, such that } \\
\text { they will be prepared to actively } \\
\text { participate in commercial or social } \\
\text { service projects that aim to improve } \\
\text { human health and environmental } \\
\text { quality through organic practices." }\end{array}$ & New farmers & $\begin{array}{l}\text { Production practices } \\
\text { and social issues in } \\
\text { agriculture }\end{array}$ & $\begin{array}{l}\text { Courses and } \\
\text { workshops, field } \\
\text { trips, on-farm } \\
\text { training }\end{array}$ & $\begin{array}{l}\text { University of California- } \\
\text { Santa Cruz Center for } \\
\text { Agroecology and } \\
\text { Sustainable Food } \\
\text { Systems }\end{array}$ & $\mathrm{CA}$ \\
\hline $\begin{array}{l}\text { Beginning Farmer } \\
\text { and Land Access } \\
\text { Program }\end{array}$ & $\begin{array}{l}\text { "[S] upport a significant increase in } \\
\text { the number of newly established, } \\
\text { successful farmers over the next five } \\
\text { to seven years. The program will } \\
\text { focus on preparing beginning farmers } \\
\text { for early business success, and } \\
\text { helping beginning farmers gain } \\
\text { access to production resources, such } \\
\text { as land and capital." }\end{array}$ & New farmers & $\begin{array}{l}\text { Equipment acquisi- } \\
\text { tion, funding, land } \\
\text { acquisition and } \\
\text { transfer, networking, } \\
\text { resources }\end{array}$ & $\begin{array}{l}\text { Advising and } \\
\text { counseling, } \\
\text { networking, } \\
\text { resource/guide }\end{array}$ & $\begin{array}{l}\text { Farm Service Agency, } \\
\text { Intervale Foundation, } \\
\text { Northeast Organic } \\
\text { Farming Association of } \\
\text { Vermont (NOFA-VT), } \\
\text { USDA-Natural Resources } \\
\text { Conservation Service } \\
\text { (NRCS), University of } \\
\text { Vermont (UVM) Center for } \\
\text { Sustainable Agriculture, } \\
\text { UVM Extension, Vermont } \\
\text { Agency of Agriculture, } \\
\text { Vermont Farm Bureau, } \\
\text { Vermont Land Trust, } \\
\text { Yankee Farm Credit }\end{array}$ & VT \\
\hline
\end{tabular}

a www.albafarmers.org/about.html

b casfs.ucsc.edu/training/infoap.html

c www.uvm.edu/ susagctr/?Page=begland.html= 


\begin{tabular}{|c|c|c|c|c|c|c|}
\hline Initiative & Mission/Purpose & Audience & Content Area & Educational Format & Social Context & Location(s) \\
\hline $\begin{array}{l}\text { Beginning Farmer } \\
\text { Center }\end{array}$ & $\begin{array}{l}\text { "Coordinate education programs and } \\
\text { services for beginning farmer efforts } \\
\text { statewide; assess needs of beginning } \\
\text { farmers and retiring farmers; develop, } \\
\text { coordinate, and deliver targeted edu- } \\
\text { cation to beginning and retiring farm } \\
\text { families; provide programs and serv- } \\
\text { ices that develop skills and } \\
\text { knowledge in financial management } \\
\text { and planning, legal issues, tax laws, } \\
\text { technical production and manage- } \\
\text { ment, sustainable agriculture, human } \\
\text { health, the environment, and } \\
\text { leadership." }\end{array}$ & $\begin{array}{l}\text { Beginning and } \\
\text { retiring farmers }\end{array}$ & $\begin{array}{l}\text { Business planning } \\
\text { and management, } \\
\text { land acquisition and } \\
\text { transfer, } \\
\text { legal issues }\end{array}$ & $\begin{array}{l}\text { Advising and } \\
\text { counseling, college } \\
\text { seminar, online } \\
\text { resources and/or } \\
\text { guides }\end{array}$ & $\begin{array}{l}\text { lowa State University } \\
\text { Extension }\end{array}$ & IA \\
\hline Beginning Farmers & $\begin{array}{l}\text { "[D]evelop a comprehensive and up- } \\
\text { to-date compilation of information } \\
\text { resources for new, experienced, and } \\
\text { potential farmers, as well as } \\
\text { educators, activists, and } \\
\text { policymakers interested in the } \\
\text { development of new farm } \\
\text { enterprises." }\end{array}$ & $\begin{array}{l}\text { New, } \\
\text { experienced, } \\
\text { and potential } \\
\text { farmers; } \\
\text { educators, } \\
\text { activists, and } \\
\text { policymakers }\end{array}$ & $\begin{array}{l}\text { Business planning } \\
\text { and management, } \\
\text { educational } \\
\text { opportunities, funding, } \\
\text { land acquisition and } \\
\text { transfer, network } \\
\text { building, production }\end{array}$ & Online resource & $\begin{array}{l}\text { Michigan State } \\
\text { University }\end{array}$ & MI \\
\hline $\begin{array}{l}\text { Center for Rural } \\
\text { Affairs: Beginning } \\
\text { Farmer and } \\
\text { Rancher } \\
\text { Opportunities }\end{array}$ & $\begin{array}{l}\text { "Helps beginning farmers and } \\
\text { ranchers gain access to the land, } \\
\text { financing, knowledge and skills that } \\
\text { they need to make a successful } \\
\text { start." }^{\text {f }}\end{array}$ & $\begin{array}{l}\text { Beginning } \\
\text { farmers }\end{array}$ & $\begin{array}{l}\text { Business planning } \\
\text { and management, } \\
\text { funding, land } \\
\text { acquisition and } \\
\text { transfer, marketing }\end{array}$ & $\begin{array}{l}\text { Advising and } \\
\text { counseling, } \\
\text { networking, } \\
\text { resources and } \\
\text { publications }\end{array}$ & Center for Rural Affairs & NE \\
\hline $\begin{array}{l}\text { Collaborative } \\
\text { Regional Alliance } \\
\text { for Farmer } \\
\text { Training }\end{array}$ & $\begin{array}{l}\text { "[A] cooperative effort of local organic } \\
\text { and biodynamic farms organized to } \\
\text { enhance educational opportunities } \\
\text { for farm apprentices." }\end{array}$ & $\begin{array}{l}\text { Beginning } \\
\text { farmers and } \\
\text { apprentices }\end{array}$ & $\begin{array}{l}\text { Marketing, } \\
\text { networking, } \\
\text { production }\end{array}$ & $\begin{array}{l}\text { Farm tours, } \\
\text { networking, } \\
\text { workshops }\end{array}$ & $\begin{array}{l}\text { Regionalized farmer-led } \\
\text { apprentice network }\end{array}$ & $\begin{array}{l}\text { KY, IL, MA, } \\
\text { NY, WI, } \\
\text { Canada }\end{array}$ \\
\hline
\end{tabular}




\begin{tabular}{|c|c|c|c|c|c|c|}
\hline Initiative & Mission/Purpose & Audience & Content Area & Educational Format & Social Context & Location(s) \\
\hline $\begin{array}{l}\text { Cultivating } \\
\text { Success }\end{array}$ & $\begin{array}{l}\text { "[l]ncrease producer and consumer } \\
\text { understanding, value, and support of } \\
\text { sustainable local farming systems in } \\
\text { Washington and ldaho through } \\
\text { educational and experiential } \\
\text { opportunities." }\end{array}$ & $\begin{array}{l}\text { Beginning, } \\
\text { existing and } \\
\text { immigrant } \\
\text { farmers }\end{array}$ & $\begin{array}{l}\text { Business planning } \\
\text { and management, } \\
\text { goal-setting, legal } \\
\text { issues, marketing, } \\
\text { production, resource } \\
\text { evaluation, social } \\
\text { issues }\end{array}$ & $\begin{array}{l}\text { Courses, internship, } \\
\text { mentorship }\end{array}$ & $\begin{array}{l}\text { Rural Roots, University } \\
\text { of Idaho, Washington } \\
\text { State University }\end{array}$ & ID, WA \\
\hline $\begin{array}{l}\text { Education for } \\
\text { American } \\
\text { Agriculture }\end{array}$ & $\begin{array}{l}\text { "[P]rovide the tools needed for NYFEA } \\
\text { to address the question: 'Where will } \\
\text { we find the next generation of young } \\
\text { and beginning producers and young } \\
\text { agribusiness professionals?"'i }\end{array}$ & $\begin{array}{l}\text { Young (adult) } \\
\text { beginning } \\
\text { farmers }\end{array}$ & $\begin{array}{l}\text { Business planning } \\
\text { and management, } \\
\text { leadership, social } \\
\text { issues }\end{array}$ & $\begin{array}{l}\text { Varies from state to } \\
\text { state; focus on } \\
\text { online courses and } \\
\text { networking }\end{array}$ & $\begin{array}{l}\text { National Young Farmers } \\
\text { Education Association }\end{array}$ & National \\
\hline $\begin{array}{l}\text { Exploring the } \\
\text { Small Farm } \\
\text { Dream: Is Starting } \\
\text { an Agricultural } \\
\text { Business Right for } \\
\text { You? }\end{array}$ & $\begin{array}{l}\text { "[D]esigned to help aspiring farmers } \\
\text { learn what it takes to start and } \\
\text { mange a commercial agricultural } \\
\text { business, and decide whether this is } \\
\text { a path they really want to take." }\end{array}$ & $\begin{array}{l}\text { Prospective, } \\
\text { explorers, early } \\
\text { stage planners }\end{array}$ & $\begin{array}{l}\text { Business assessment, } \\
\text { decision-making, goal- } \\
\text { setting, values } \\
\text { assessment }\end{array}$ & Course & $\begin{array}{l}\text { New England Small } \\
\text { Farm Institute, Pioneer } \\
\text { Valley Enterprise } \\
\text { Program }\end{array}$ & $\begin{array}{l}\text { MA, NJ, } \\
\text { NY, OH, } \\
\text { PA, RI, VA, } \\
\text { Canada }\end{array}$ \\
\hline Farm Beginnings & $\begin{array}{l}\text { "[A] Land Stewardship Project } \\
\text { initiative that provides opportunities } \\
\text { for beginning and transitioning } \\
\text { farmers to learn firsthand about } \\
\text { values clarification and goal setting, } \\
\text { whole farm planning, business plan } \\
\text { development, and low-cost, } \\
\text { sustainable farming methods."k }\end{array}$ & $\begin{array}{l}\text { Beginning and } \\
\text { transition } \\
\text { farmers }\end{array}$ & $\begin{array}{l}\text { Business planning } \\
\text { and management, } \\
\text { goal-setting, } \\
\text { marketing, production, } \\
\text { online resources } \\
\text { and/or guides }\end{array}$ & $\begin{array}{l}\text { Classroom } \\
\text { sessions, farm } \\
\text { tours, mentorships }\end{array}$ & $\begin{array}{l}\text { Dakota Rural Action, } \\
\text { Foundation for } \\
\text { Agricultural and Rural } \\
\text { Resources Management } \\
\text { and Sustainability } \\
\text { (FARRMS), Hawthorne } \\
\text { Valley Farm, The Land } \\
\text { Connection, Lake } \\
\text { Superior Sustainable } \\
\text { Farming Association, } \\
\text { Land Stewardship } \\
\text { Project, Nebraska } \\
\text { Extension, University of } \\
\text { Illinois }\end{array}$ & $\begin{array}{l}\text { MN, IL, } \\
\text { NE, NY, } \\
\text { ND, SD, } \\
\text { WI }\end{array}$ \\
\hline
\end{tabular}

h www.cultivatingsuccess.org/about.htm

i www.nyfea.org/ed-Idrship-programs.html

j growingnewfarmers.org/main/for_new_farmers/exploring_the_small_farm_dream/

k www.landstewardshipproject.org/fb/whatisfb.html 


\begin{tabular}{|c|c|c|c|c|c|c|}
\hline Initiative & Mission/Purpose & Audience & Content Area & Educational Format & Social Context & Location(s) \\
\hline $\begin{array}{l}\text { Farm Viability } \\
\text { Enhancement } \\
\text { Program }\end{array}$ & $\begin{array}{l}\text { "[I]mprove the economic viability and } \\
\text { environmental integrity of } \\
\text { participating farms through the } \\
\text { development and implementation of } \\
\text { farm viability plans." }\end{array}$ & $\begin{array}{l}\text { New farmers } \\
\text { with at least } \\
\text { two years } \\
\text { experience }\end{array}$ & $\begin{array}{l}\text { Business planning } \\
\text { and management }\end{array}$ & $\begin{array}{l}\text { Advising and } \\
\text { counseling }\end{array}$ & $\begin{array}{l}\text { Massachusetts } \\
\text { Department of } \\
\text { Agricultural Resources }\end{array}$ & MA \\
\hline $\begin{array}{l}\text { Georgia Organics } \\
\text { Mentoring } \\
\text { Program }\end{array}$ & $\begin{array}{l}\text { "[D]evelop the capacity of farmers } \\
\text { and farms committed to sustainable } \\
\text { agriculture and land stewardship."m }\end{array}$ & $\begin{array}{l}\text { New, } \\
\text { transitioning, } \\
\text { and limited- } \\
\text { resource } \\
\text { farmers }\end{array}$ & $\begin{array}{l}\text { Determined by mentor } \\
\text { and program } \\
\text { participants }\end{array}$ & $\begin{array}{l}\text { Advising and } \\
\text { counseling, annual } \\
\text { conference, on-farm } \\
\text { training, workshops }\end{array}$ & $\begin{array}{l}\text { Georgia Organics, Inc., } \\
\text { Risk Management } \\
\text { Agency (RMA) }\end{array}$ & $\mathrm{GA}$ \\
\hline $\begin{array}{l}\text { The Greenhorns } \\
\text { for Beginning } \\
\text { Farmers }\end{array}$ & $\begin{array}{l}\text { "[S]upport, promote and recruit young } \\
\text { farmers in America." }\end{array}$ & $\begin{array}{l}\text { Young and } \\
\text { beginning } \\
\text { farmers }\end{array}$ & $\begin{array}{l}\text { Business planning } \\
\text { and management, } \\
\text { land acquisition and } \\
\text { transfer, marketing, } \\
\text { production, sustain- } \\
\text { able agriculture }\end{array}$ & $\begin{array}{l}\text { Farmer-based } \\
\text { resource guide, } \\
\text { social media, social } \\
\text { networking }\end{array}$ & The Greenhorns & NY \\
\hline $\begin{array}{l}\text { Grow Your Farm: } \\
\text { Successful whole } \\
\text { farm management }\end{array}$ & $\begin{array}{l}\text { "[D]esigned for prospective farmers, } \\
\text { beginners with some experience and } \\
\text { seasoned farmers who want to make } \\
\text { a 'new beginning' with alternative } \\
\text { farming methods." }\end{array}$ & $\begin{array}{l}\text { Prospective, } \\
\text { beginning and } \\
\text { restrategizing } \\
\text { farmers }\end{array}$ & $\begin{array}{l}\text { Business planning } \\
\text { and management, } \\
\text { marketing, resource } \\
\text { assessment, values } \\
\text { assessment }\end{array}$ & Course, networking & $\begin{array}{l}\text { University of Missouri } \\
\text { Extension }\end{array}$ & MO \\
\hline Growing Farms & $\begin{array}{l}\text { "[P]rovide beginning specialty crop } \\
\text { and livestock farmers with the tools } \\
\text { and knowledge to manage both the } \\
\text { biological and financial risks of } \\
\text { farming." }\end{array}$ & New farmers & $\begin{array}{l}\text { Business planning } \\
\text { and management } \\
\text { financial planning, } \\
\text { funding, legal issues, } \\
\text { marketing, production, } \\
\text { resource evaluation, } \\
\text { values assessment }\end{array}$ & $\begin{array}{l}\text { Course, field trips, } \\
\text { networking }\end{array}$ & $\begin{array}{l}\text { Oregon State University } \\
\text { Extension Small Farms } \\
\text { Program }\end{array}$ & OR \\
\hline
\end{tabular}

I www.mass.gov/agr/programs/farmviability/

m www.georgiaorganics.org/farming/

${ }^{n}$ www.thegreenhorns.net/reading.html

o extension.missouri.edu/growyourfarm/

$\stackrel{p}{p}$ smallfarms.oregonstate.edu/growing-farms-workshop-series 


\begin{tabular}{|c|c|c|c|c|c|c|}
\hline Initiative & Mission/Purpose & Audience & Content Area & Educational Format & Social Context & Location(s) \\
\hline $\begin{array}{l}\text { Growing New } \\
\text { Farmers }\end{array}$ & $\begin{array}{l}\text { "[H]elp new or aspiring farmers get } \\
\text { the training they need to go out on } \\
\text { their own and to get started farming } \\
\text { with affordable expenditures for } \\
\text { equipment and land rental."q }\end{array}$ & $\begin{array}{l}\text { New or aspiring } \\
\text { farmers }\end{array}$ & $\begin{array}{l}\text { Business planning } \\
\text { and management; } \\
\text { equipment, land and } \\
\text { resource acquisition; } \\
\text { production }\end{array}$ & $\begin{array}{l}\text { Internship, } \\
\text { incubator program }\end{array}$ & Farm Catskills & NY \\
\hline $\begin{array}{l}\text { Growing New } \\
\text { Farmers Project } \\
\text { and Consortium }\end{array}$ & $\begin{array}{l}\text { "E]stablish an effective, responsive } \\
\text { and enduring service infrastructure } \\
\text { that, through creative integration of } \\
\text { research, extension and education } \\
\text { provides future generations of } \\
\text { Northeast farmers with the support } \\
\text { and farming expertise they need to } \\
\text { succeed."r }\end{array}$ & New farmers & $\begin{array}{l}\text { Business planning } \\
\text { and management, } \\
\text { marketing, funding, } \\
\text { land acquisition and } \\
\text { transfer, network } \\
\text { building, production, } \\
\text { technical skill }\end{array}$ & $\begin{array}{l}\text { Varies for each } \\
\text { partner: Advising } \\
\text { and counseling, } \\
\text { courses, online } \\
\text { courses, network- } \\
\text { ing, on-farm training }\end{array}$ & $\begin{array}{l}\text { Consortium partners } \\
\text { from government } \\
\text { agencies, nongovern- } \\
\text { mental organizations, } \\
\text { and university and } \\
\text { extension associations }\end{array}$ & $\begin{array}{l}\text { GNF } \\
\text { Consor- } \\
\text { tium } \\
\text { members } \\
\text { in CT, DE, } \\
\text { MA, MD, } \\
\text { ME, NH, } \\
\text { NJ, NY, PA, } \\
\text { RI, VT, WV }\end{array}$ \\
\hline $\begin{array}{l}\text { Michigan State } \\
\text { University Organic } \\
\text { Farmer Training } \\
\text { Program }\end{array}$ & $\begin{array}{l}\text { "[C]ommitted to successfully } \\
\text { preparing graduates to operate their } \\
\text { own farm or community food system } \\
\text { endeavor. Graduates will be qualified } \\
\text { to run small-scale farms, work closely } \\
\text { with existing farmers, and be } \\
\text { advocates of local food systems } \\
\text { based on first hand experience and } \\
\text { training with local organic } \\
\text { production."s }\end{array}$ & $\begin{array}{l}\text { New and } \\
\text { beginning } \\
\text { farmers, urban } \\
\text { and community } \\
\text { farmers and } \\
\text { gardeners }\end{array}$ & Production, marketing & $\begin{array}{l}\text { On-farm training, } \\
\text { courses, workshops }\end{array}$ & $\begin{array}{l}\text { Michigan State } \\
\text { University }\end{array}$ & $\mathrm{MI}$ \\
\hline
\end{tabular}

a farmcatskills.org/index.cfm?category=4

r www.smallfarm.org/main/special_projects/growing_new_farmers/about_gnf/

s www.msuorganicfarm.org/goals.htm 


\begin{tabular}{|c|c|c|c|c|c|c|}
\hline Initiative & Mission/Purpose & Audience & Content Area & Educational Format & Social Context & Location(s) \\
\hline $\begin{array}{l}\text { National Farm } \\
\text { Transition Network }\end{array}$ & $\begin{array}{l}\text { "[S] upport programs that foster the } \\
\text { next generation of farmers and } \\
\text { ranchers." }\end{array}$ & $\begin{array}{l}\text { Beginning } \\
\text { farmers }\end{array}$ & $\begin{array}{l}\text { Farm land acquisition } \\
\text { and transfer, but } \\
\text { programs vary from } \\
\text { state to state }\end{array}$ & $\begin{array}{l}\text { Varies for each } \\
\text { partner: Advising } \\
\text { and counseling, } \\
\text { courses, network- } \\
\text { ing, on-farm } \\
\text { training, online } \\
\text { resources, } \\
\text { workshops }\end{array}$ & $\begin{array}{l}\text { Formal network of } \\
\text { government agencies, } \\
\text { nongovernmental } \\
\text { organizations, and } \\
\text { university and extension } \\
\text { associations }\end{array}$ & $\begin{array}{l}\text { Farm/ } \\
\text { Land Link } \\
\text { programs } \\
\text { in CA, CT, } \\
\text { IA, MA, ME, } \\
\text { MI, MN, } \\
\text { MT, NC, NE, } \\
\text { NH, NJ, NY, } \\
\text { OH, PA, RI, } \\
\text { VA, VT, WA, } \\
\text { WI }\end{array}$ \\
\hline $\begin{array}{l}\text { The New American } \\
\text { Sustainable } \\
\text { Agriculture Project }\end{array}$ & $\begin{array}{l}\text { "[D]eliver focused outreach and } \\
\text { technical assistance, including } \\
\text { educational programs, to limited- } \\
\text { resources immigrant farmers, helping } \\
\text { them to build successful Maine farms } \\
\text { that are consistent with their cultural } \\
\text { and lifestyle aspirations." }\end{array}$ & $\begin{array}{l}\text { Recently } \\
\text { resettled } \\
\text { refugee } \\
\text { farmers and } \\
\text { immigrant } \\
\text { farmworkers }\end{array}$ & $\begin{array}{l}\text { Business planning, } \\
\text { financial resource } \\
\text { acquisition, technical } \\
\text { assistance }\end{array}$ & $\begin{array}{l}\text { Advising and } \\
\text { counseling, courses } \\
\text { and workshops, on- } \\
\text { farm training }\end{array}$ & Coastal Enterprises Inc. & ME \\
\hline $\begin{array}{l}\text { New Entry } \\
\text { Sustainable } \\
\text { Farming Project } \\
\text { (New Entry) }\end{array}$ & $\begin{array}{l}\text { "[A]ssist people with limited } \\
\text { resources who have an interest in } \\
\text { small-scale commercial agriculture, to } \\
\text { begin farming in Massachusetts. The } \\
\text { broader goals of New Entry are to } \\
\text { support the vitality and sustainability } \\
\text { of the region's agriculture, to build } \\
\text { long term economic self-reliance and } \\
\text { food security among participants and } \\
\text { their communities, and to expand } \\
\text { access to high-quality, culturally } \\
\text { appropriate foods in underserved } \\
\text { areas through production of locally- } \\
\text { grown foods."v }\end{array}$ & $\begin{array}{l}\text { Prospective or } \\
\text { established } \\
\text { farmers, } \\
\text { limited } \\
\text { resource } \\
\text { farmers, } \\
\text { immigrant } \\
\text { farmers }\end{array}$ & $\begin{array}{l}\text { Business planning, } \\
\text { production, resource } \\
\text { acquisition }\end{array}$ & $\begin{array}{l}\text { On-farm training, } \\
\text { technical } \\
\text { assistance, } \\
\text { workshops }\end{array}$ & $\begin{array}{l}\text { Collaborative partners } \\
\text { from government } \\
\text { agencies, nongovern- } \\
\text { mental organizations, } \\
\text { and university and } \\
\text { extension associations }\end{array}$ & MA \\
\hline
\end{tabular}

t www.farmtransition.org/aboutnetw.html

u www.ceimaine.org/content/view/115/164/

$\checkmark$ nesfp.nutrition.tufts.edu/about/index.html 


\begin{tabular}{|c|c|c|c|c|c|c|}
\hline Initiative & Mission/Purpose & Audience & Content Area & Educational Format & Social Context & Location(s) \\
\hline $\begin{array}{l}\text { New Farmer } \\
\text { Development } \\
\text { Project }\end{array}$ & $\begin{array}{l}\text { "[l]dentifies, educates, and supports } \\
\text { immigrants with agricultural } \\
\text { experience by helping them become } \\
\text { local farmers and establish small } \\
\text { farms in the region." }{ }^{\prime w}\end{array}$ & $\begin{array}{l}\text { Immigrants } \\
\text { with farming } \\
\text { experience }\end{array}$ & $\begin{array}{l}\text { Funding, land } \\
\text { acquisition, marketing }\end{array}$ & $\begin{array}{l}\text { Advising and } \\
\text { counseling, } \\
\text { courses, mentoring, } \\
\text { technical } \\
\text { assistance }\end{array}$ & $\begin{array}{l}\text { Collaborative partners } \\
\text { from government } \\
\text { agencies, nongovern- } \\
\text { mental organizations, } \\
\text { and university and } \\
\text { extension associations }\end{array}$ & $\begin{array}{l}\text { NJ, NY, } \\
\text { Northern } \\
\text { PA }\end{array}$ \\
\hline $\begin{array}{l}\text { New Farmer } \\
\text { Foundation Year }\end{array}$ & $\begin{array}{l}\text { "[A]n exploration into biodynamic and } \\
\text { organic agriculture through } \\
\text { theoretical and experiential building } \\
\text { on core competencies and skills and } \\
\text { agro-ecological literacy. The New } \\
\text { Farmer Foundation Year prepares } \\
\text { students for the challenges of } \\
\text { farming, broadens awareness into } \\
\text { issues of sustainable agriculture } \\
\text { today and penetrates the human } \\
\text { spirit with enlivened knowledge." }\end{array}$ & New farmers & $\begin{array}{l}\text { Business planning } \\
\text { and management, } \\
\text { network-building, } \\
\text { marketing, production }\end{array}$ & $\begin{array}{l}\text { Courses and } \\
\text { workshops, field } \\
\text { trips, on-farm } \\
\text { training }\end{array}$ & $\begin{array}{l}\text { Michael Fields } \\
\text { Agricultural Institute }\end{array}$ & WI \\
\hline $\begin{array}{l}\text { New York } \\
\text { Beginning Farmers }\end{array}$ & $\begin{array}{l}\text { "[E]nhance the likelihood of success } \\
\text { of new ag enterprises by making the } \\
\text { best resources and training available } \\
\text { to any new or diversifying farmer in } \\
\text { NY." y }\end{array}$ & $\begin{array}{l}\text { New, aspiring, } \\
\text { beginning, and } \\
\text { diversifying } \\
\text { farmers }\end{array}$ & $\begin{array}{l}\text { Business planning } \\
\text { and management, } \\
\text { goal-setting, land and } \\
\text { resource assessment, } \\
\text { legal issues, } \\
\text { marketing }\end{array}$ & $\begin{array}{l}\text { Online course, } \\
\text { resources, webinar }\end{array}$ & $\begin{array}{l}\text { Cornell Cooperative } \\
\text { Extension, Cornell Dept. } \\
\text { of Education, Heifer } \\
\text { International, Northeast } \\
\text { Organic Farming Associ- } \\
\text { ation of New York (NOFA- } \\
\text { NY), New York FarmNet } \\
\text { and NY FarmLink, NY } \\
\text { Farm Viability Institute, } \\
\text { NY Association of Ag } \\
\text { Educators }\end{array}$ & NY \\
\hline
\end{tabular}

w www.cenyc.org/greenmarket/nfdp

x michaelfieldsaginst.org/work/education/foundation/index.shtml

y www.nybeginningfarmers.org/index.php?page=NYBFP 


\begin{tabular}{|c|c|c|c|c|c|c|}
\hline Initiative & Mission/Purpose & Audience & Content Area & Educational Format & Social Context & Location(s) \\
\hline Next Generation & $\begin{array}{l}\text { "Designed to help beginning farmer } \\
\text { PFI members thrive and farm families } \\
\text { transition their operation to the next } \\
\text { generation." }\end{array}$ & $\begin{array}{l}\text { Beginning } \\
\text { farmers }\end{array}$ & $\begin{array}{l}\text { Business planning } \\
\text { and management, } \\
\text { goal setting, land } \\
\text { acquisition and } \\
\text { transfer, marketing, } \\
\text { production }\end{array}$ & $\begin{array}{l}\text { Annual retreat, farm } \\
\text { tours, mentoring, } \\
\text { networking, } \\
\text { workshops and } \\
\text { courses, webinars }\end{array}$ & $\begin{array}{l}\text { Practical Farmers of } \\
\text { lowa }\end{array}$ & IA \\
\hline $\begin{array}{l}\text { People Learning } \\
\text { Agriculture Now for } \\
\text { Tomorrow (PLANT) }\end{array}$ & $\begin{array}{l}\text { "[S]eeks to revitalize agricultural } \\
\text { activity in the Piedmont Region } \\
\text { through training on small scale } \\
\text { sustainable farming techniques." }\end{array}$ & $\begin{array}{l}\text { Farm trainees } \\
\text { and } \\
\text { apprentices }\end{array}$ & $\begin{array}{l}\text { Business planning } \\
\text { and management, } \\
\text { marketing, production }\end{array}$ & Workshops & $\begin{array}{l}\text { North Carolina } \\
\text { Cooperative Extension }\end{array}$ & NC \\
\hline $\begin{array}{l}\text { School for } \\
\text { Beginning Dairy } \\
\text { and Livestock } \\
\text { Farmers }\end{array}$ & $\begin{array}{l}\text { "[P]rovide the opportunity for } \\
\text { motivated individuals to educate } \\
\text { themselves about pasture-based } \\
\text { dairy and livestock farming." }\end{array}$ & New farmers & $\begin{array}{l}\text { Business planning } \\
\text { and management, } \\
\text { production }\end{array}$ & $\begin{array}{l}\text { Courses and } \\
\text { workshops, farm } \\
\text { tours, internships }\end{array}$ & $\begin{array}{l}\text { University of Wisconsin- } \\
\text { Madison }\end{array}$ & WI \\
\hline The Seed Farm & $\begin{array}{l}\text { "An agricultural incubator program for } \\
\text { the establishment of new sustainable } \\
\text { farms and farmers. The mission of } \\
\text { the seed farm is to plant the seeds } \\
\text { for the future of a viable and } \\
\text { environmentally sustainable Lehigh } \\
\text { Valley agricultural economy and to } \\
\text { facilitate the growth of a vibrant } \\
\text { Lehigh Valley local food system."cc }\end{array}$ & New farmers & $\begin{array}{l}\text { Business planning } \\
\text { and management, } \\
\text { goal setting, land } \\
\text { acquisition, } \\
\text { marketing, production, } \\
\text { resource assessment, } \\
\text { values assessment }\end{array}$ & $\begin{array}{l}\text { Apprenticeships, } \\
\text { farm tours, } \\
\text { mentoring, } \\
\text { workshops and } \\
\text { courses }\end{array}$ & $\begin{array}{l}\text { Penn State Cooperative } \\
\text { Extension Service, PA } \\
\text { government agencies, } \\
\text { nongovernmental } \\
\text { organizations }\end{array}$ & PA \\
\hline $\begin{array}{l}\text { Small and } \\
\text { Beginner Farmers } \\
\text { of New Hampshire }\end{array}$ & $\begin{array}{l}\text { "[A] farmer to farmer network with the } \\
\text { goals of connecting farmers and the } \\
\text { community, sharing ideas and } \\
\text { information, and accessing technical } \\
\text { assistance and agricultural } \\
\text { education."dd }\end{array}$ & New farmers & $\begin{array}{l}\text { Funding, marketing, } \\
\text { production }\end{array}$ & $\begin{array}{l}\text { Listserv, farm tours, } \\
\text { mentoring, online } \\
\text { classifieds, } \\
\text { resource and/or } \\
\text { guide, workshops }\end{array}$ & $\begin{array}{l}\text { Small and Beginner } \\
\text { Farmers of New } \\
\text { Hampshire }\end{array}$ & $\mathrm{NH}$ \\
\hline
\end{tabular}

z www.practicalfarmers.org/programs/youth-and-next-generation.html

aa www.orangecountyfarms.org/PLANTatBreeze.asp

bb www.cias.wisc.edu/dairysch.html

cc sites.google.com/site/theseedfarm/

$\infty$ dd www.sbfnh.org/index.php?option=com_content\&task=view\&id=13\&ltemid=1 


\begin{tabular}{|c|c|c|c|c|c|c|}
\hline Initiative & Mission/Purpose & Audience & Content Area & Educational Format & Social Context & Location(s) \\
\hline $\begin{array}{l}\text { Vermont New } \\
\text { Farmer Network }\end{array}$ & $\begin{array}{l}\text { "[A] working group of agricultural } \\
\text { organizations committed to serving } \\
\text { the needs of new and aspiring } \\
\text { farmers in Vermont."ee }\end{array}$ & $\begin{array}{l}\text { New and } \\
\text { aspiring } \\
\text { farmers in } \\
\text { Vermont }\end{array}$ & $\begin{array}{l}\text { Business planning } \\
\text { and management, } \\
\text { marketing, funding, } \\
\text { land acquisition and } \\
\text { transfer, network- } \\
\text { building, production, } \\
\text { technical skills }\end{array}$ & $\begin{array}{l}\text { Resource guide, } \\
\text { social networking, } \\
\text { workshops }\end{array}$ & $\begin{array}{l}\text { Informal network of } \\
\text { government agencies, } \\
\text { nongovernmental } \\
\text { organizations, university } \\
\text { and extension } \\
\text { associations }\end{array}$ & VT \\
\hline $\begin{array}{l}\text { Women's } \\
\text { Agricultural } \\
\text { Network }\end{array}$ & $\begin{array}{l}\text { "Through a series of educational, } \\
\text { technical assistance, and networking } \\
\text { opportunities, WAgN works to } \\
\text { increase the number of women } \\
\text { owning and operating profitable } \\
\text { farms and ag-related businesses, as } \\
\text { well as their profile in leadership } \\
\text { positions throughout the agricultural } \\
\text { sectors of business, government and } \\
\text { community."ff }\end{array}$ & $\begin{array}{l}\text { Prospective } \\
\text { and beginning } \\
\text { female farmers }\end{array}$ & $\begin{array}{l}\text { Business planning } \\
\text { and management, } \\
\text { decision-making, goal- } \\
\text { setting, marketing, } \\
\text { resource evaluation }\end{array}$ & $\begin{array}{l}\text { Courses and work- } \\
\text { shops, learning } \\
\text { circles }\end{array}$ & $\begin{array}{l}\text { Collaborative partners } \\
\text { from government } \\
\text { agencies, nongovern- } \\
\text { mental organizations, } \\
\text { university and extension } \\
\text { associations }\end{array}$ & $\begin{array}{l}\text { WAgN } \\
\text { projects in } \\
\text { CT, ME, } \\
\text { PA, VT }\end{array}$ \\
\hline $\begin{array}{l}\text { Young Farmers } \\
\text { and Ranchers } \\
\text { Program }\end{array}$ & $\begin{array}{l}\text { “[P]rovide leadership in building a } \\
\text { more effective Farm Bureau to } \\
\text { preserve our individual freedoms and } \\
\text { expand our opportunities in } \\
\text { agriculture."gg }\end{array}$ & $\begin{array}{l}\text { Young farmers } \\
\text { and ranchers } \\
\text { (18 to } 35 \text { years } \\
\text { old) }\end{array}$ & Networking & $\begin{array}{l}\text { Varies for each } \\
\text { program: courses } \\
\text { and workshops, } \\
\text { farm tours, and } \\
\text { networking }\end{array}$ & American Farm Bureau & National \\
\hline
\end{tabular}

ee www.vermontagriculture.com/agdev/new\%20farmers/vnfn.htm

ff www.uvm.edu/wagn/?Page=about/index.html\&SM=about/sub-menu.html

gg www.fb.org/index.php?fuseaction=young.young 


\section{References}

Ahearn, M. C. \& Newton, D. J. (2009). Beginning farmers and ranchers, EIB-53, U.S. Department of Agriculture, Economic Research Service. Retrieved on April 18, 2010, from www.ers.usda.gov/Publications/ EIB53/EIB53.pdf.

Ahearn, M. C., Yee, J., \& Korb, P. (2005). Effects of differing farm policies on farm structure and dynamics. American Journal of Agricultural Economics, 87(5), 1182-89.

Allen, P. (2004). Together at the table: Sustainability and sustenance in the American agrifood system. University Park, Pennsylvania: Pennsylvania University Press.

Allen, P. \& Sachs, C. (1993). Sustainable agriculture in the United States: Engagements, silences, and possibilities for transformation. In P. Allen (Ed.), Food for the future: Conditions and contradictions of sustainability (pp. 139-68). New York, NY: Wiley \& Sons.

Bird, G. W., \& Ikerd, J. (1993). Sustainable agriculture: A twenty-first-century system. Annals of the American Academy of Political Science, 592(1), 92-102.

Butler, M. B., \& Flora, C. B. (2006). Expanding visions of sustainable agriculture. In C. Francis, R. Poincelot, \& G. Bird (Eds.), Developing and extending sustainable agriculture: A new social contract (pp. 203 224). Binghamton, NY: Haworth Press.

Cervero, R. M., \& Wilson, A. L. (2001). At the heart of practice: The struggle for knowledge and power. In R. Cervero \& A. Wilson (Eds.), Power in practice: Adult education and the struggle for knowledge and power in society (pp. 1-20). San Francisco, CA: Jossey-Bass.

Chambers, R. (1997). Whose reality counts? Putting the first last. London: Intermediate Technology Publications.

Danbom, D. B. (1986). Publicly sponsored agricultural research in the United States from an historical perspective. In K. Dahlberg (Ed.), New directions in agriculture and agricultural research: Neglected dimensions and emerging alternatives (pp. 107-131). Totowa, NJ: Rowman \& Allenheld.

Farm Security and Rural Investment Act of 2002, H.R. 2646, 107th Cong. (2002). Retrieved December 12, 2009, from www.fas.usda.gov/excredits/FoodAid/ Farm Bill 2002.pdf.

Food, Conservation, and Energy Act of 2008, H.R. 2419, 110 ${ }^{\text {th }}$ Cong. (2008). Retrieved December 12, 2009, from frwebgate.access.gpo.gov/cgi-bin/ getdoc.cgi?dbname=110_cong_bills\&docid=f:h2419 enr.txt.pdf.

Freire, P. (1973). Education for critical consciousness. New York: Continuum Publishing Company.
Gillespie, G. W. (2004, March). Findings from research on new farmers. Workshop (with S. E. Johnson) at the Keep on Growing New Farmers conference of the Growing New Farmers Project and Consortium, Windsor, CT.

Hassanein, N. (1999). Changing the way America farms: Knowledge and community in the sustainable agriculture movement. Lincoln: University of Nebraska Press.

Hassanein, N. (2003). Practicing food democracy: A pragmatic politics of transformation. Journal of Rural Studies, 19(1), 77-86.

Hassanein, N., \& Kloppenburg, J. (1995). Where the grass grows again: Knowledge exchange in the sustainable agriculture movement. Rural Sociology, 60(4), 721-40.

Heady, E. O. (1957). Adaptation of extension education and auxiliary aids to the basic economic problem of agriculture. Journal of Farm Economics, 39(1), 112-27.

Hesterman, O. B. (2006). Impacts of private foundations on sustainable agriculture and food systems. In C. Francis, R. Poincelot, \& G. Bird (Eds.), Developing and extending sustainable agriculture: $A$ new social contract (pp. 261-287). Binghamton, NY: Haworth Press.

Hinrichs, C. C. (2007). Introduction: Practice and place in remaking the food system. In C. C. Hinrichs \& T. A. Lyson (Eds), Remaking the North American food system: Strategies for sustainability (pp. 1-15). Lincoln: University of Nebraska Press.

Kloppenburg, J. R., Jr. (1991). Social theory and the $\mathrm{de} /$ reconstruction of agricultural science: Local knowledge for an alternative agriculture. Rural Sociology, 56(4), 519-548.

Lamberti, A. (2007). Talking the talk: Revolution in agricultural communication. New York: Nova Science Publishers.

Liepins, R., \& Schick, R. (1998). Gender and education: Towards a framework for a critical analysis of agricultural training. Sociologia Ruralis, 38(3), 286-302.

Lockeretz, W., \& Anderson, M. D. (1993). Agricultural research alternatives. Lincoln: University of Nebraska Press.

Lyson, T. A. (2004). Civic agriculture: Reconnecting farm, food, and community. Medford, MA: Tufts University Press.

Nelson, D. R., \& Trede, L. D. (2004). Educational needs of beginning farmers as perceived by Iowa Extension professional staff. Journal of Extension, 42(1). Retrieved December 29, 2009, from www.joe.org/joe/2004february/rb2.php.

Nickerson, C., \& Hand, M. (2009). Participation in conservation programs by targeted farmers: Beginning, limited-resource, and socially 
disadvantaged operators' enrollment trends. EIB-62, U.S. Department of Agriculture, Economic Research Service. Retrieved April 18, 2010, from www.ers. usda.gov/Publications/EIB62/EIB62.pdf.

Niewolny, K. L.(2007). Growing new farmers or producing new producers? A critical discourse analysis of the Growing New Farmers Consortium, 2000-2005. Unpublished doctoral dissertation, Cornell University.

Niewolny, K. L., \& Wilson, A. (2007). Economic knowledge production of the Growing New Farmers Consortium, 2000-2005: A critical discourse analysis of adult agricultural education. In L. Servage \& T. Fenwick (Eds.), Proceedings of the 48th Annual Adult Education Research Conference (pp. 45762). Halifax, NS: Mount Saint Vincent University.

Phipps, L. (1956). Agricultural education. Review of Educational Research, 26(4), 359-69.

Poincelot, R., Francis, C., \& Bird, G. (2006). Overview of the educational social contract: Building a foundation for sustainable agriculture. In C. Francis, R. Poincelt, \& G. Bird (Eds.), Developing and extending sustainable agriculture: A new social contract (pp. 1-23). Binghamton, NY: Haworth Press.

Pretty, J. N. (1995). Participatory learning for sustainable agriculture. World development, 23(8), 1247-63.

Rasmussen, W. (1960). Readings in the history of American agriculture. Urbana: University of Illinois Press.

Röling, N., \& deJong, F. (1998). Learning: Shifting paradigms in education and extension studies. Journal of Agricultural Education and Extension, 5(3), 143-61.

Röling, N., \& Wagemakers, A. (1998). Facilitating sustainable agriculture: Participatory learning and adaptive management in times of environmental uncertainty. Cambridge, UK: Cambridge University Press.

Ruhf, K. Z. (2001). Northeast new farmers: Opportunities for policy development. New England Small Farm Institute, Belchertown, MA. Retrieved December 12, 2009, from www.smallfarm.org/uploads/uploads/ Files/Policy Background Paper.pdf.

Schön, D. A. (1983). The reflective practitioner: How professionals think in action. New York, NY: Basic Books.
Sheils, C., \& Descartes, M. (2004). Addressing gaps in new farmer programming. In C. Sheils \& M. Descartes, Working with new farmers: Topics in professional development (pp. 14-19). The New England Small Farm Institute: GNF Professional Development Component, Belchertown, MA.

Shortall, S. (1996). Training to be farmers or wives? Agricultural training for women in Northern Ireland. Sociologia Ruralis, 36(3), 269-85.

Trauger, A., Sachs, C., Barbercheck, M., Kiernan, N. E., Brasier, K., \& Findeis, J. (2008). Agricultural education: Gender identity and knowledge exchange. Journal of Rural Studies, 24(4), 432-39.

Trede, L. D., \& Whitaker, S. (1998). Beginning farmer education in Iowa: Implications to Extension. Journal of Extension, 36(5). Retrieved December 29, 2009, from www.joe.org/joe/1998october/a3.html.

U.S. Department of Agriculture. (2006). Small and beginning farmers and ranchers policy. Departmental Regulation 9700-001, Office of the Chief Economist. Washington, DC. Retrieved December 12, 2009, from www.ocio.usda.gov/directives/doc/ DR9700-001.pdf.

U.S. Department of Agriculture, National Agricultural Statistics Service. (2009). 2007 census of agriculture, United States summary and state data. Vol. 1, Geographic Area Series, Part 51, AC-07-A-51. Washington, DC. Retrieved December, 12, 2009, from www.agcensus.usda.gov/Publications/ 2007/Full Report/usv1.pdf.

U.S. Department of Agriculture, National Institute of Food and Agriculture. (2009). Beginning farmer and rancher development program. Retrieved December 10, 2009, from www.csrees.usda.gov/fo/beginning farmerandrancher.cfm.

U.S. Department of Labor, Bureau of Labor Statistics (2009). Employment projections. Washington, DC: Retrieved March 21, 2010, from www.bls.gov/ emp/ep table 105.htm. 